\title{
Analysis Of The Effect Of Online Convenience Dimensions On Customer Satisfaction And Behavioral Intention Of Tokopedia Customers In Surabaya
}

\author{
Arif Surianggo, Amelia ${ }^{\mathrm{b}}$, Ronald ${ }^{\mathrm{*} *}$ \\ a arif.surianggo@gmail.com \\ ${ }^{a}$ Master of Management Student at Pelita Harapan University, Surabaya 60234, Indonesia \\ ${ }^{b, c}$ The Lecturer of Master of Management at Pelita Harapan University, Surabaya 60234, Indonesia
}

\begin{abstract}
The development of technology in the current era of globalization has increased rapidly and rapidly. Technological developments have influenced individual lifestyles in a more modern direction by keeping up with the times. This of course will have a big impact in aspects of life, especially the business world. One of them is the emergence of internet technology. Internet is the most effective communication and information media that can reach all people. The internet is also the most popular medium used as a land for doing business, which is better known as e-commerce (electronic commerce). This study aims to analyze the influence of the variable access convenience, search convenience, evaluation convenience, attentiveness convenience, transaction convenience, convenience position, post position convenience, on behavioral intention through customer satisfaction of Tokopedia application users in Surabaya. The sample used in this study is based on data from 155 male and female respondents, domiciled in Surabaya, with an age limit of 18-60 years. The questionnaire was given to respondents who have installed the Tokopedia application on a smartphone, have used the Tokopedia application at least 2 times in the last 6 (six) months, have made direct purchases for personal needs through the Tokopedia application on smartphones 2 times in the last 6 months, have interacted with Tokopedia's customer service in the last 6 months, and aware of the Tokopedia application promotions. For processing and analyzing data in this study using SPSS 22.0. Furthermore, to tabulate the results of the respondents' research, as well as to test the research model is to use the Structural Equation Model (SEM) data analysis technique. These empirical findings indicate that the relationship of access convenience has a significant effect on customer satisfaction with a regression coefficient of 0.161 ; search convenience has a significant effect on customer satisfaction with a regression coefficient of 0.130 ; evaluation convenience has a significant effect on customer satisfaction with a regression coefficient of 0.284; Attentiveness convenience has a significant effect on customer satisfaction with a regression coefficient of 0.108 ; transaction convenience has a significant effect on customer satisfaction with a regression coefficient of 0.115 ; possesion convenience has a significant effect on customer satisfaction with a regression coefficient of 0.142 ; possesion convenience has a significant effect on customer satisfaction with a regression coefficient of 0.118 ; Customer satisfaction has a significant effect on behavioral intention with a regression coefficient of 0.845 .
\end{abstract}

Keywords: Access Convenience, Search Convenience, Evaluation Convenience, Attentiveness Convenience, Transaction Convenience, Possesion Convenience, Post-Possesion Convenience, Customer Satisfaction, Behavioral Intention, ECommerce

\section{Introduction}

The development of technology in the current era of globalization has increased rapidly and rapidly. Technological developments have influenced individual lifestyles in a more modern direction by keeping up with the times. This of course will have a big impact in aspects of life, especially the business world. One of 
them is the emergence of internet technology. Internet is the most effective communication and information media that can reach all people. The internet is also the most popular medium used as a land for doing business, which is better known as e-commerce (electronic commerce) (akseleran.co.id, downloaded on 21 June 2020).

E-commerce (electronic commerce) is a process in which buyers and sellers can exchange information, money and merchandise electronically, especially through the internet (Peter \& Olson, 2008). Based on this definition, it can be seen that those who can participate in e-commerce activities are anyone who can access a computer, has a connection to the internet, and is able to make payments for goods and services that have been purchased electronically or electronic payment (Shelly, Cashman, Vermaat, 2007). In general, ecommerce is divided into three main categories, namely (Laudon and Jane, 2008) Company-to-consumer (business-to-consumer-B2C), company-to-company (business-to-business-B2B), and consumer- consumer-toconsumer-C2C (dictio.id, downloaded on 21 June 2020).

Indonesia has become a country that has the 5th largest number of internet users in the world. We Are Social's latest report, in 2020 it is stated that there are 175.4 million internet users in Indonesia. Compared to the previous year, there was an increase of $17 \%$ or 25 million internet users in this country. Based on the total population of Indonesia, which amounts to 272.1 million, it means that $64 \%$ of the Indonesian population has experienced access to cyberspace (detik.com downloaded on June 9, 2020).

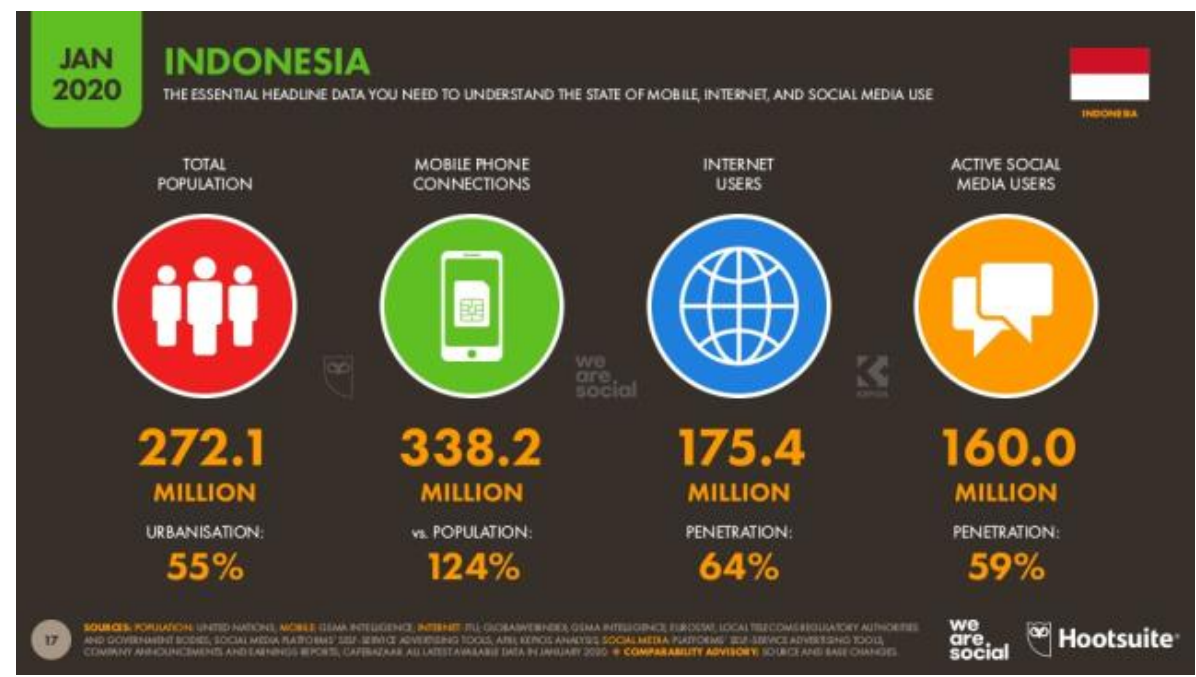

Figure 1.1 Data of internet users around the world in 2020.

Source: (wearesocial.com downloaded on May 16, 2020)

The internet has now become a necessity, not except for the Indonesian people. According to research on the social media management platform HootSuite and social marketing agency We Are Social entitled "Global Digital Reports 2020", nearly 64 percent of Indonesia's population is connected to the internet. The research released at the end of January 2020 stated that the number of internet users in Indonesia had reached 175.4 million people, while the total population of Indonesia was around 272.1 million. Compared to 2019, the number of internet users in Indonesia has increased by around 17 percent or 25 million users. During 2019, internet users in Indonesia aged 16 to 64 have an average of 7 hours 59 minutes per day to surf in cyberspace. This figure exceeds the global average which only spends 6 hours 43 minutes on the internet per day (kumparan.com downloaded on June 9, 2020). 
The faster growth of internet users has made internet-based businesses in Indonesia also grow faster. The e-commerce business is an internet-based business that has benefited the most from the rapid growth of the internet in Indonesia. Indonesia is now one of the fastest growing economies in the world. Among the various sectors that are involved in it, e-commerce is one of the most promising thanks to the widespread application of technology. Internet users in Indonesia are expected to increase by 50 million people by 2020 . This rapid growth will certainly increase the use of e-commerce as a trading intermediary platform in the years to come (ekrut.com, downloaded on June 9, 2020) .

E-commerce is a new way for Indonesians to shop. Currently, Indonesians are getting used to shopping online. In 2016, the number of e-commerce users in Indonesia was in the range of 24.9 million. This number continues to creep up to reach 31.65 million users in 2018. This number is expected to continue to grow, reaching 39.2 million users in 2020, 42.1 million users in 2021, and 43.9 million users in 2022. On average, the e-commerce users will spend around 5 million rupiah to shop online. Indonesians spend an average of 4 hours 48 minutes using computers and 3 hours 55 minutes using mobile devices. Most of the mobile devices used are in the form of smart phones or smartphones (ekrut.com, downloaded on 10 June 2020).

There are two types of e-commerce that get the most investment funds in Indonesia, namely $\mathrm{C} 2 \mathrm{C}$ (consumer to consumer) and B2C (business to consumer) e-commerce. In B2C, the e-commerce company is the seller. Whereas in $\mathrm{C} 2 \mathrm{C}$, the company is a platform provider that brings together sellers and buyers. Therefore, if consumers choose to shop on $\mathrm{C} 2 \mathrm{C}$ e-commerce sites, consumers must choose which products from which sellers they want to buy. One of the advantages of shopping through e-commerce is that the product price is cheaper. In $\mathrm{C} 2 \mathrm{C}$ e-commerce, the role of price is very crucial compared to $\mathrm{B} 2 \mathrm{C}$ e-commerce. A product in $\mathrm{C} 2 \mathrm{C}$ e-commerce can be sold by many sellers and buyers can choose to buy from one of these online sellers / shops (softwareseni.co.id, downloaded on 16 June 2020).

One of the largest C2C e-commerce companies in Indonesia is Tokopedia. Tokopedia is an online marketplace that allows individuals and business owners in Indonesia to open and manage their online store easily and free of cost, while providing a safe and comfortable online buying and selling experience. Tokopedia was founded on August 17, 2009, with the vision of "Building a better Indonesia through the Internet". Tokopedia provides items such as men's and women's fashion, electronic equipment, kitchen utensils, household appliances, hobbies, baby supplies, office supplies, mobile credit, travel tickets, etc. Then tokopedia collaborates with several courier services for the process of sending goods to customers (niagahoster.co.id, downloaded on July 8, 2020).

In accordance with the characteristics of an e-commerce $\mathrm{C} 2 \mathrm{C}$ company, Tokopedia is a platform to bring together sellers and buyers on the internet. Sellers who want to sell their goods can register on Tokopedia and upload the products they want to sell on Tokopedia. The product information will be displayed on the Tokopedia platform, so that buyers can find the product they want to buy. The Tokopedia platform also displays seller information such as seller name, location, price and so on. Not only that, Tokopedia also displays information that represents seller credibility such as reputation, sales rating and number of products sold (seller.tokopedia.com/, downloaded on July 6, 2020)

Tokopedia provides a storefront for sellers to open their shop on the Tokopedia site. Almost all categories are available here, from product services to services. Of course, with more and more features and services available in Tokopedia, certain regulations and criteria are needed before sellers open their shops on Tokopedia. There are several rules and standards created by Tokopedia for convenience between sellers and buyers. For example, products that do not comply with the Tokopedia storefront criteria, Tokopedia will immediately conduct moderation, namely moving products to warehouses, moderating shops, and permanently closing shops due to products that do not comply with the provisions or regulations that apply in Tokopedia (dailysocial .id, downloaded on July 8, 2020). 
With the increasing number of internet users in Indonesia, it will encourage the growth of the ecommerce industry in Indonesia. According to data from the editorial staff of Tempo, the results show that the value of e-commerce transactions in Indonesia in 2016 reached 4.89 billion US dollars. The access used to make online purchases via a computer or tablet was 21.14 million and only 12.82 million via smartphones. Based on the 2015 Online Shopping Outlook research conducted by BMI Research, it is revealed that the opportunity for e-commerce growth is still very large along with the increasing number of internet users in Indonesia (Apkomindo, 2015).

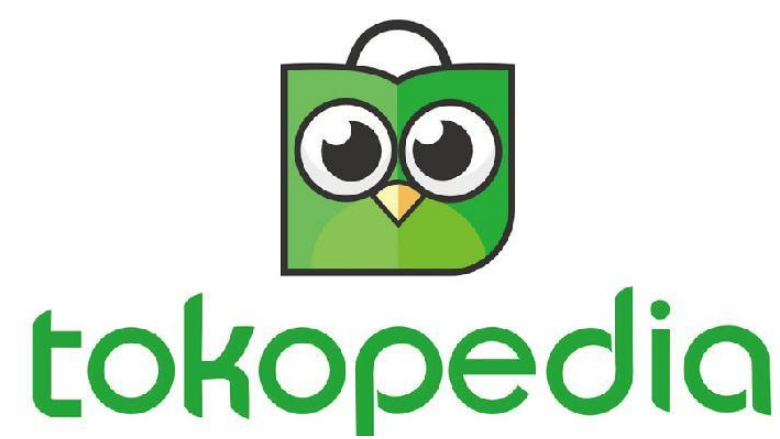

Figure 1.2 Display of the Tokopedia Logo

Source: (www.google.com, downloaded on June 16, 2020)

Tokopedia has a motto that is "Just Start First" During its 10 years of journey, Tokopedia has gone through challenge after challenge, step by step, until finally it reaches the point of success. Tokopedia believes that success cannot be achieved without a small step (https: // www. tokopedia.com/about/, downloaded on June 16, 2020). Tokopedia has 3 features that cannot be found on other e-commerce sites, namely: Success story: a feature that makes a place to share inspiration for success stories from someone who has been particularly successful. selling as a seller on Tokopedia, Behind the scene: a unique feature provided by Tokopedia in terms of sharing secrets, namely showing consumers and audiences how the kitchen works and how they work starting from the cohesiveness of the workers who are commonly referred to as Nakama, and a picture of the work space The story of the establishment of Tokopedia: through this feature the reader will be taken to trace the history of Dar i Tokopedia was founded today.

The first research gap in this study is the effect of convenience variables on customer satisfaction based on the results of previous studies conducted by Duartea, Silvab, Ferreirab (2018), there is a significant influence between convenience and customer satisfaction. Where when customers feel the covenience provided by e-commerce companies will increase customer satisfaction. However, this contradicts the results of research conducted by Mala Srivastavaa and Dimple Kaulb (2014) which states that convenience does not have a significant direct effect on customer satisfaction. This is because in this study it was found that the research has a mediating variable, namely customer experience, which shows that customer experience fully mediates the relationship between the two antecedents of customer satisfaction. Therefore, this study was conducted to ascertain whether convenience has a significant effect on customer satisfaction whether or not it has a significant or insignificant effect for companies in the e-commerce field.

This study focuses on discussing the variables that affect the behavioral intention of Tokopedia customers in Surabaya. So that it can be used by management as a corrective measure to ensure an increase in Behavioral Intention in the Tokopedia company which in turn has an effect on increasing company performance. 


\section{Litterature Review}

\subsection{Theories and Hypotheses}

\subsubsection{Access Convenience}

According to Duarte (2018) access convenience is defined as the perception of consumers' time and effort expenditure to initiate service delivery. According to Mehmood and Najmi (2017), access convenience is important for customers, because if they have a problem regarding a product, brand or delivery date, then they need a service provider to facilitate them in solving their problem.

\section{H1: Access Convenience has a significant effect on Customer Satisfaction}

\subsubsection{Search Convenience}

Beauchamp and Ponder (2010) define search convenience as the speed and ease with which consumers identify and select the products they want to buy. Sabine et al. (2016) stated that search convenience has the greatest importance on customer satisfaction.

\section{H2: Search Convenience has a significant effect on Customer Satisfaction}

\subsubsection{Evaluations Convenience}

Evaluation convenience is associated with the availability of detailed but easy-to-understand product descriptions using various presentation features, such as text, graphics, and videos, provided by the company or seller (Duarte, 2018). The results of research by Janda et al. (2002) and Szymanski and Hise (2000) who state that evaluation convenience is an important factor in influencing consumer satisfaction in online shopping.

H3: Evaluation Convenience has a significant effect on Customer Satisfaction

\subsubsection{Attentiveness Convenience}

According to Luedi (1997) and Madu (2002) argue that Attentiveness Convenience is a recorded strong competition in the online market, exposition only for the catalog of products or services on the Web is not sufficient to guarantee the survival of online retailers. The considerate dimension refers to the extent to which online retailers provide personalized service and attention to customers. According to Pappas et al., (2016) Attentiveness Convenience has a significant effect on customer satisfaction.

\section{H4: Attentiveness Convenience has a significant effect on Customer Satisfaction}

\subsubsection{Transaction Convenience}

According to Beauchamp and Ponder (2010), transaction convenience is defined as the speed and convenience with which consumers can influence or change transactions. Research from Grewal et al (2002) shows that convenience in transactions such as ease of payment, ease of concluding goods to be purchased (shopping carts) is also related to customer satisfaction.

\section{H5: Transaction Convenience has a significant effect on Customer Satisfaction}

\subsubsection{Possesion Convenience}

Possesion convenience represents an effort in terms of time and money that consumers have to spend to have what they want and the level of ease of buying a product in an application (Jiang et al., 2013). According to Jiang et al., (2013) found that convenience possesion has a significant effect on customer satisfaction.

H6: Possesion Convenience has a significant effect on Customer Satisfaction 


\subsubsection{Post-Possesion Convenience}

According to Berry et al. (2002) post-possesion convenience becomes important after service exchange and relates to the perceived time the consumer feels and the expense of restarting contact with the company after purchasing the product in question. According to Berry et al., (2002) found the role of Post-Possesion Convenience in increasing customer satisfaction.

\section{H7: Post-Possesion Convenience has a significant effect on Customer Satisfaction}

\subsubsection{Customer Satisfaction}

According to Lovelock and Wirtz (2012), customer satisfaction is an attitude and assessment of the characteristics or features of the product or service itself that provides a level of consumer enjoyment related to meeting consumer consumption needs. Han and Ryu (2007) found increasing customer satisfaction was very important for increasing return visits and recommendation intentions.

\section{H8: Customer Satisfaction has a significant effect on Behavioral Intention}

\subsubsection{Behavioral Intentions}

According to Jani and Han (2011), behavioral intention includes the intention of consumers to make return visits. The same thing was stated by Zeithaml et al. (2009), behavioral intention is a willingness to recommend services provided to others and a willingness to make repeat purchases.

\subsection{Research Model}

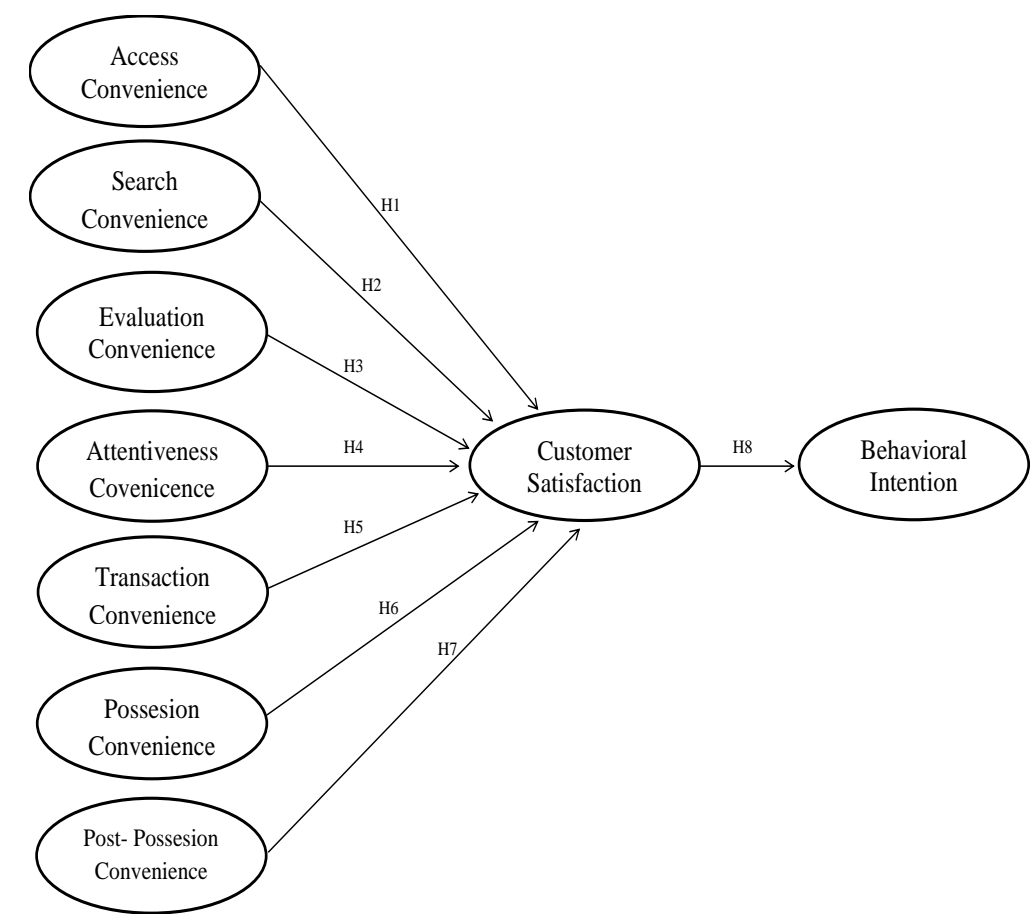

Figure 2.1: The Framework of Research Model 


\section{Research Methods}

The research method used in this research is quantitative research. The population used is customers who use the Tokopedia application in Surabaya. The sampling technique used was non-probability sampling using a questionnaire as the main tool in data collection. This technique is used because the actual population size is unknown, in other words, the individual does not have the same possibility of being sampled. The area used as a place for distributing questionnaires is the city of Surabaya. The questionnaire was given to Tokopedia application users, so that the selected respondents match what was expected. In the study, it had 31 indicators, so the sample in this study was 31 indicators multiplied by 5 equal to 155 samples, therefore, the respondents in this study were 155 respondents. The questionnaire in this study will be divided into two parts. The first part contains questions to obtain general information about the respondent which is useful for determining the suitability of the characteristics of the respondent with the sample criteria. The second part contains several statements to obtain research data and analyze the effect of access convenience, search convenience, convenience evaluation, attentiveness convenience, transaction convenience, convenience possession, and post-position convenience through customer satisfaction and behavioral intention. The scale used in this study is the Likert scale. where answers are provided with the interval from strongly disagree (STS) to strongly agree (SS).

\section{Results and Discussion}

\subsection{Assessment of Measurement Model}

Table 4.1: Multiple Regression AC, SC, EC, ATC, TC, PC, PPC to Customer Satisfaction

\begin{tabular}{|c|c|c|c|c|c|c|c|c|}
\hline \multirow{2}{*}{\multicolumn{2}{|c|}{ Model }} & \multicolumn{2}{|c|}{$\begin{array}{c}\text { Unstandardized } \\
\text { Coefficients }\end{array}$} & \multirow{2}{*}{$\begin{array}{c}\text { Standardized } \\
\text { Coefficients } \\
\text { Beta }\end{array}$} & \multirow[b]{2}{*}{$\mathrm{t}$} & \multirow[b]{2}{*}{ Sig. } & \multicolumn{2}{|c|}{ Collinearity Statistics } \\
\hline & & $\mathrm{B}$ & Std. Error & & & & Tolerance & VIF \\
\hline \multirow[t]{8}{*}{1} & (Constant) & -.904 & .152 & & -5.943 & .000 & & \\
\hline & $A C$ & .206 & .056 & .161 & 3.641 & .000 & .370 & 2.703 \\
\hline & SC & .145 & .068 & .130 & 2.126 & .035 & .193 & 5.178 \\
\hline & EC & .343 & .066 & .284 & 5.236 & .000 & .246 & 4.064 \\
\hline & ATC & .115 & .050 & .108 & 2.293 & .023 & .323 & 3.097 \\
\hline & TC & .129 & .062 & .115 & 2.076 & .040 & .234 & 4.272 \\
\hline & PC & .149 & .071 & .142 & 2.119 & .036 & .162 & 6.182 \\
\hline & PPC & .132 & .058 & .118 & 2.257 & .025 & .263 & 3.807 \\
\hline
\end{tabular}

a. Dependent Variable: CS 
Table 4.2: Single Regression Customer Satisfaction to Behavioral Intentions

\begin{tabular}{|c|c|c|c|c|c|c|c|c|}
\hline \multirow{2}{*}{\multicolumn{2}{|c|}{ Model }} & \multicolumn{2}{|c|}{$\begin{array}{c}\text { Unstandardized } \\
\text { Coefficients }\end{array}$} & \multirow{2}{*}{$\begin{array}{c}\text { Standardized } \\
\text { Coefficients } \\
\text { Beta }\end{array}$} & \multirow[b]{2}{*}{$\mathrm{t}$} & \multirow[b]{2}{*}{ Sig. } & \multicolumn{2}{|c|}{ Collinearity Statistics } \\
\hline & & $\mathrm{B}$ & Std. Error & & & & Tolerance & VIF \\
\hline \multirow[t]{2}{*}{1} & (Constant) & .786 & .175 & & 4.492 & .000 & & \\
\hline & CS & .821 & .042 & .845 & 19.566 & .000 & 1.000 & 1.000 \\
\hline
\end{tabular}

a. Dependent Variable: BI

Multiple regression test shows the influence of an independent variable on the dependent variable. The condition for a hypothesis is considered significant when the significance level is less than $0.05(\alpha=$ $5 \%)$. So that the results in this study are explained as follows:

\subsection{Hypotheses Testing}

Table 4.4: Summary of Testing Results.

\begin{tabular}{|l|l|}
\hline Hypotheses & Analysis \\
\hline H1: Access convenience has a significant effect on customer satisfaction. & Accepted \\
\hline H2: Search convenience has a significant effect on customer satisfaction. & Accepted \\
\hline H3: Evaluation convenience has a significant effect on customer satisfaction. & Accepted \\
\hline H4: Attentiveness convenience has a significant effect on customer satisfaction. & Accepted \\
\hline H5: Transaction convenience has a significant effect on customer satisfaction. & Accepted \\
\hline H6: Possesion convenience has a significant effect on customer satisfaction. & Accepted \\
\hline H7: Post-possesion convenience has a significant effect on customer satisfaction. & Accepted \\
\hline H8: Customer Satisfaction has a significant effect on behavioral intention. & Accepted \\
\hline
\end{tabular}

\subsection{Discussion}

\subsubsection{The effect of Access convenience on customer Satisfaction}

The first hypothesis is that access convenience has a significant effect on customer satisfaction. This hypothesis is supported by the $\mathrm{t}$ test where the significance is 0.000 (below 0.05) which indicates that this hypothesis is accepted. Mehmood and Najmi (2017) found a significant relationship between access convenience and customer satisfaction. An application will create convenience for its users if users feel they can shop anytime they want on the service provider application then the user can also order products in the service provider application wherever they are, it will increase customer satisfaction, feel overall satisfied with the products provided, satisfied with the product price, satisfied because they had a generally positive experience and app users found the service provider's application easy to access.

\subsubsection{The effect of Search convenience on customer Satisfaction}

The second hypothesis is that seacrch convenience has a significant effect on customer satisfaction. This hypothesis is supported by the t test where the significance is 0.035 (below 0.05) which indicates that this hypothesis is accepted. According to Beauchamp and Ponder $(2010,52)$, defines search convenience as a file The speed and ease with which consumers identify and select the products they want to buy. Tokopedia Application users find the service provider application easy to use to purchase products that have been selected by consumers. Tokopedia users should also feel that the service provider application is easy to 
navigate within the application. The intended navigation is to make it easier for consumers to immediately know what to do immediately to make transactions. And Users should also be able to find the product they want quickly in the service provider application by educating sellers to provide detailed product titles and descriptions.

\subsubsection{The effect of Evaluation convenience on customer Satisfaction}

The third hypothesis is evaluation convenience has a significant effect on customer satisfaction. This hypothesis is supported by the $t$ test where the significance is 0.000 (below 0.05) which indicates that this hypothesis is accepted. Iwan and Boy (2015) argue that evaluation convenience can be used to increase profit and customer satisfaction. If a company ensures that each product has detailed specifications, this will have an impact on high customer satisfaction because customers think that the company is informative and educates consumers. However, if a company does not have detailed specifications, then this can create confusion in the minds of customers so that customer satisfaction is low. The results showed that evaluation convenience of the Tokopedia application is good because the seller uses clear text in product information, it will improve customer satisfaction, feel overall satisfied with the description of the products provided, satisfied with product prices, satisfied because they have a positive general experience, use appropriate images in product information and feel that the Tokopedia application provides sufficient information to identify various products.

\subsubsection{The effect of Attentiveness convenience on customer Satisfaction}

The fourth hypothesis is that attentiveness convenience has a significant effect on customer satisfaction. This hypothesis is supported by the $t$ test where the significance is 0.023 (below 0.05) which indicates that this hypothesis is accepted. According to Pappas et al., (2016), online customers expect special attention, personalized services are better tailored to their needs which helps them reduce the effort and time required to seek information and reach purchasing decisions. The purpose of expecting special attention is not only representing various concerns in the form of chat, but also explaining the benefits and functions of the product to consumers. If the retail company is able to create good convenience attentiveness in the eyes of the public, it will affect customer satisfaction. From the results of the study, it was found that the attentiveness convenience of the Tokopedia application users in Surabaya, namely that they felt the Tokopedia application had a message area for questions and answers with the shop, and received my detailed personal spending records via email after I ordered on the Tokopedia application, it would increase customers. satisfaction, feeling overall satisfaction with the products provided, satisfied with product prices, satisfied because they have a general positive experience, and feeling satisfied with the service from the Tokopedia application Seller.

\subsubsection{The effect of Transaction convenience on customer Satisfaction}

The fifth hypothesis is that transaction convenience has a significant effect on customer satisfaction. This hypothesis is supported by the t test where the significance is 0.040 (below 0.05) which indicates that this hypothesis is accepted. According to Sabine et al. (2017) transaction convenience is one of the most important dimensions towards customer satisfaction. The purpose of transaction convenience is not only towards customer satisfaction, but also providing flexible payment methods for consumers. If the Tokopedia application is able to create transaction convenience that is good in the eyes of the public, it will affect customer satisfaction. From the research results, it was found that the transaction convenience of Tokopedia application users in Surabaya, namely feeling that the check-out process on the Tokopeida application was fast service, felt that my purchase in the Tokopedia application was completed easily, felt it didn't take long to complete the purchase process on the Tokopedia application, and users feel safe to provide personal data on 
the Tokopedia application, it will increase customer satisfaction, feel overall satisfied with the products provided, satisfied with the payment method, satisfied because it has an easy transaction experience, and is satisfied with many types of payment methods both debit and credit from the Tokopedia application.

\subsubsection{The effect of Possesion convenience on customer Satisfaction}

The sixth hypothesis is that convenience position has a significant effect on customer satisfaction. This hypothesis is supported by the $t$ test where the significance is 0.036 (below 0.05) which indicates that this hypothesis is accepted. Menrutu Jiang et al., (2013) Convenience of ownership represents an effort in terms of time and money that consumers have to spend to have what they want. The meaning of convenience of ownership is not only to have what they want, but also to send consumer orders on time by the Tokopedia app Seller. If the Tokopedia application is able to create possession convenience that is good in the eyes of the public, it will affect customer satisfaction. From the results of the study, it was found that the possession convenience of Tokopedia application users in Surabaya, namely feeling that the check-out process on the Tokopeida application was fast service, felt that the goods sent by service provider application sellers were not damaged, it would increase customer satisfaction, feel overall satisfaction with the services provided. provided, on time delivery, and warranty for goods that are not damaged and defective from the seller of the Tokopedia application.

\subsubsection{The effect of Post-Possesion convenience on customer Satisfaction}

The seventh hypothesis is post position convenience has a significant effect on customer satisfaction. This hypothesis is supported by the $t$ test where the significance is 0.025 (below 0.05) which indicates that this hypothesis is accepted. According to Berry et al., (2002) Post-ownership convenience becomes important after service exchange and is related "to the consumer's perceived time and expenditure when re-initiating contact with the company after purchasing the product in question". The purpose of post-ownership convenience is not only to have what they want after purchase, but consumers can also easily take care of returning products purchased through the Tokopedia application. If the Tokopedia application is able to create post possession convenience that is good in the eyes of the public, it will affect customer satisfaction. From the results of the study, it was found that the post possession convenience of Tokopedia application users in Surabaya, that they feel that handling the exchange of products purchased through the Tokopedia application can be done easily, and any problems after purchasing that consumers experience are quickly resolved by the Tokopedia application, it will increase customer satisfaction, feel overall satisfied with the services provided and products that have run out will be immediately claimed for a refund through the Tokopedia application.

\subsubsection{The effect of Customer Satisfaction on Behavioral Intention}

The eighth hypothesis is that customer satisfaction has a significant effect on behavioral intention. This hypothesis is supported by the $t$ test where the significance is 0.000 (below 0.05) which indicates that this hypothesis is accepted. Han and Ryu (2007) state that customer satisfaction has a significant effect on behavioral intention. The occurrence of behavioral intention depends on the evaluation results of previous purchases. After carrying out the purchase process, consumers tend to evaluate how high the level of satisfaction is from the purchase, so that it can determine the strength or weakness of behavioral intention. The higher the satisfaction felt by consumers, the stronger the consumer's behavioral intention, and vice versa, if the level of satisfaction from the previous purchase is low, the behavioral intention will also be low (Anderson and Sullivan (1993)). From the results of the study, it was found that customer satisfaction with the Tokopedia application users in Surabaya, namely being satisfied overall with the products provided, being satisfied with product prices, being satisfied because having a positive general experience, and being satisfied with employee service, will increase behavioral intention to frequently provide more detailed information 
about online transaction services on Tokopedia to users, invite consumers to increase the use of online transactions in the Tokopedia application, and make Tokopedia the first choice when making transactions.

\section{Conclusion}

Based on the data processing that has been done, the results show that eight hypotheses are accepted and no hypothesis is rejected. There is a significant relationship between access convenience to customer satisfaction, search convenience to customer satisfaction, evaluation convenience to customer satisfaction, convenience convenience to customer satisfaction, transaction convenience to customer satisfaction, possession convenience to customer satisfaction, post possession convenience to customer satisfaction and customer satisfaction towards behavioral intention.

\subsection{Managerial Implications}

Table 5.1: Managerial Implications

\begin{tabular}{|c|c|}
\hline Current Research & Managerial Implications \\
\hline $\begin{array}{l}\text { Access convenience is } \\
\text { defined as consumers' } \\
\text { perceived time and effort } \\
\text { expenditure to initiate } \\
\text { service delivery (Duarte } \\
2018 \text { ) }\end{array}$ & $\begin{array}{l}\text { - Upgrading the Tokopedia system so that consumers can place orders } \\
\text { from abroad. For example: when a customer in Malaysia wants to place } \\
\text { an order for delivery to Malaysia. } \\
\text { - Tokopedia makes simple video tutorials for new users, and makes some } \\
\text { specific tutorials about the features provided so that if customers are } \\
\text { confused they can see interactive videos according to the information } \\
\text { needs needed. } \\
\text { - Tokopedia adds various payment services that can facilitate consumer } \\
\text { transactions in purchasing goods such as debit, credit, virtual accounts } \\
\text { that cover all banks or payments via supermarkets }\end{array}$ \\
\hline $\begin{array}{l}\text { Search convenience is the } \\
\text { speed and convenience of } \\
\text { consumers identifying and } \\
\text { choosing the products they } \\
\text { want to buy (Beauchamp and } \\
\text { Ponder 2010) }\end{array}$ & $\begin{array}{l}\text { - Tokopedia provides a side bar that contains Tokopedia features so that } \\
\text { when you open one feature and want to open another feature, you don't } \\
\text { need to gradually return it to the homepage. } \\
\text { - Tokopedia equips all products in the Tokopedia application by finding } \\
\text { out what products are trending and popular at the time and providing a } \\
\text { happening lifestyle feature. } \\
\text { - Tokopedia provides game features that contain information about all the } \\
\text { features and programs offered by Tokopedia in an attractive form such as } \\
\text { Games. It is hoped that games that offer reward points that can be } \\
\text { exchanged will make customers even more excited to find out about the } \\
\text { features available in Tokopedia. }\end{array}$ \\
\hline $\begin{array}{l}\text { Evaluation convenience is } \\
\text { associated with the } \\
\text { availability of detailed yet } \\
\text { easy-to-understand product } \\
\text { descriptions using various } \\
\text { presentation features, such as } \\
\text { text, graphics, and videos, } \\
\text { provided by the company or } \\
\text { seller (Duarte 2018) }\end{array}$ & $\begin{array}{l}\text { - Tokopedia provides Indonesian that is clear and easy to understand by } \\
\text { Tokopedia application users and makes the Tokopedia application have a } \\
\text { variety of other languages such as English and Mandarin so that people } \\
\text { who are more familiar with these languages or foreigners who live in } \\
\text { Indonesia can also shop at Tokopedia. } \\
\text { - Tokopedia educates sellers to upload photos with a good and clear } \\
\text { design. The Tokopedia application may also provide templates for } \\
\text { editing product photos to be uploaded directly. } \\
\text { - Tokopedia to create a template with a minimum number of words that }\end{array}$ \\
\hline
\end{tabular}




\begin{tabular}{|c|c|}
\hline & $\begin{array}{l}\text { must be filled in by the seller in relation to the product being sold, where } \\
\text { if the number of words has not reached the minimum it cannot be } \\
\text { uploaded. } \\
\text { - Tokopedia maintains and improves this indicator by providing product } \\
\text { information not only in the form of a description, sellers can add real } \\
\text { photos and video clips to the products offered so that they can convince } \\
\text { potential consumers more so that potential consumers can see and know } \\
\text { firsthand the product which is on sale. In addition, so far in Tokopedia } \\
\text { there are still many sellers who have not completed the product with } \\
\text { sufficient information such as size, color, function and so on. Therefore, } \\
\text { Tokopedia needs to require sellers to provide all existing product } \\
\text { identifications, otherwise they cannot automatically upload products. }\end{array}$ \\
\hline $\begin{array}{l}\text { Attentiveness Convenience } \\
\text { is additional time to increase } \\
\text { time and effort. To retain } \\
\text { customers, modern online } \\
\text { retailers use a variety of } \\
\text { personalization features to } \\
\text { differentiate their products } \\
\text { and services from the } \\
\text { competition based on service } \\
\text { customization and } \\
\text { personalization (Junetal } \\
\text { 2004) }\end{array}$ & $\begin{array}{l}\text { - Tokopedia provides specific and detailed proof of purchase each month } \\
\text { where these recapitations are differentiated based on spending } \\
\text { specifications. This detailed record makes it easy for the customer to } \\
\text { browse and plan for learning } \\
\text { - Tokopedia provides chat services between buyers and consumers in real } \\
\text { time so that they can ask and answer questions directly about the } \\
\text { products being traded, and if they are not answered within a certain time, } \\
\text { the seller will be penalized. } \\
\text { - Tokopedia gives special gifts to Tokopedia application users at important } \\
\text { moments such as birthdays, first day of registering on the Tokopedia } \\
\text { application, national holidays, and others. Special special prizes can be in } \\
\text { the form of cashback, free shipping, and others }\end{array}$ \\
\hline $\begin{array}{l}\text { Transaction convenience as a } \\
\text { consumer's perception of } \\
\text { time and effort costs to make } \\
\text { transactions (Maulana 2018) }\end{array}$ & $\begin{array}{l}\text { - Tokopedia makes check out orders on one page making it easier for } \\
\text { customers to see the entire order. } \\
\text { - Tokopedia created a platform, for example, Tokopedia pay, which has a } \\
\text { high enough balance limit so that consumers can top up it and the pay } \\
\text { later system. So that if they want to make transactions on Tokopedia, it } \\
\text { will be easier without having to transfer via bank. } \\
\text { - Tokopedia recapitulates payment methods according to consumer } \\
\text { transaction histories so that consumers who want to shop again can } \\
\text { complete the purchase process more practically. } \\
\text { Tokopedia maintains the confidentiality of the personal data provided by } \\
\text { consumers so that there is no misuse or breach of data in the future. For } \\
\text { example, when logging in to the Tokopedia application, consumers must } \\
\text { use fingerprints and face scans. } \\
\text { - Tokopedia provides a feature that makes a monthly shopping summary } \\
\text { so that it makes it easier for customers to see a recap of monthly } \\
\text { spending and when making new purchases it will be easier to complete } \\
\text { because customers are able to quickly remember previous purchases that } \\
\text { can be used as a comparison. }\end{array}$ \\
\hline $\begin{array}{l}\text { Possesion Convenience } \\
\text { represents the effort in terms } \\
\text { of time and money that } \\
\text { consumers have to spend to }\end{array}$ & $\begin{array}{l}\text { - Tokopedia can provide personal assistance services that can help } \\
\text { customers make monthly customer planning which can be done through } \\
\text { the Tokopedia application, such as payment for water, electricity, } \\
\text { groceries, etc. And every month it provides a reminder for payments and }\end{array}$ \\
\hline
\end{tabular}




\begin{tabular}{|c|c|}
\hline $\begin{array}{l}\text { have what they want and the } \\
\text { level of ease of buying a } \\
\text { product in the application. } \\
\text { (Jiang et al 2013) }\end{array}$ & $\begin{array}{l}\text { purchases of monthly shopping lists in the customer's household. } \\
\text { Tokopedia to be able to improve this indicator by educating sellers } \\
\text { through various training to pay more attention to packaging goods } \\
\text { (packing products using boxes or bubble wrap) before sending to } \\
\text { consumers so that the products sent remain safe and complete. } \\
\text { - Tokopedia can provide chat features not only with Tokopedia and sellers } \\
\text { but also with shipping service providers so that customers and sellers can } \\
\text { ask more clearly regarding the product ordered without the need to pay to } \\
\text { call the delivery service provider. }\end{array}$ \\
\hline $\begin{array}{l}\text { Post-possession convenience } \\
\text { becomes important after } \\
\text { service exchange and relates } \\
\text { "to the perceived time the } \\
\text { consumer feels and the } \\
\text { expense of restarting contact } \\
\text { with the company after } \\
\text { purchasing the product in } \\
\text { question (Berry et al. 2002). }\end{array}$ & $\begin{array}{l}\text { - Tokopedia provides fast services for exchanging products quickly where } \\
\text { Tokopedia provides stages for product exchange procedures, starting } \\
\text { from complaints, seller responses, buyer delivery and delivery of } \\
\text { exchanged goods. In addition, it provides a feature for picking up goods } \\
\text { by the delivery service which will be exchanged by the customer. } \\
\text { - Tokopedia can increase the speed of service to Tokopedia's customer } \\
\text { care so that complaints from customers / buyers can be resolved } \\
\text { immediately, for example: providing regular training to employees } \\
\text { regarding customer service such as through the live chat feature with } \\
\text { Tokopedia Care. } \\
\text { The Tokopedia application provides a pickup service for goods to be } \\
\text { returned by consumers so that consumers do not need to send more } \\
\text { goods to the relevant expedition. }\end{array}$ \\
\hline $\begin{array}{l}\text { Customer satisfaction is an } \\
\text { attitude and an assessment of } \\
\text { the characteristics or features } \\
\text { of the product or service } \\
\text { itself that provides a level of } \\
\text { consumer pleasure related to } \\
\text { meeting consumer } \\
\text { consumption needs } \\
\text { (Lovelock and Wirtz 2012) }\end{array}$ & $\begin{array}{l}\text { - Tokopedia always maintains and even improves customer satisfaction by } \\
\text { providing the best service to application users and users can provide } \\
\text { feedback in the form of messages, impressions and suggestions for the } \\
\text { progress of the Tokopedia application. } \\
\text { - Tokopedia can maintain and increase customer satisfaction by } \\
\text { accelerating employee performance and increasing variations in payment } \\
\text { methods, such as credit cards, debit cards, and e-money. With the } \\
\text { increase in performance speed and payment methods, it is hoped that } \\
\text { customers can make payments more quickly so that other customers do } \\
\text { not take long to queue. } \\
\text { Tokopedia can maintain and even improve this indicator by adding to the } \\
\text { category of products it sells, for example, such as increasing foreign } \\
\text { products and adding domestic MSME products. }\end{array}$ \\
\hline $\begin{array}{l}\text { Behavioral intention } \\
\text { includes the intention of } \\
\text { consumers to make return } \\
\text { visits (Jani and Han 2011). }\end{array}$ & $\begin{array}{l}\text { - Tokopedia can improve this indicator by providing a loyalty program so } \\
\text { that the Tokopedia application can get greater opportunities for } \\
\text { consumers to continue shopping again. Special promos every month can } \\
\text { also be applied to customers, and always provide the latest product } \\
\text { promotions so that customers are interested in always making } \\
\text { transactions on Tokopedia. } \\
\text { - Tokopedia can maintain and even improve this indicator by holding } \\
\text { program loyalty. The advantage of implementing this program is that the } \\
\text { Tokopedia application can find out all information about loyal } \\
\text { customers, so they can find out what products these customers usually } \\
\text { buy. For example: if the consumer has reached the shopping turnover set }\end{array}$ \\
\hline
\end{tabular}




\begin{tabular}{|l|l|}
\hline & $\begin{array}{l}\text { by Tokopedia, the consumer will get a free shopping voucher worth } \\
500,000-1,000,000 \text { rupiah. By doing so, Tokopedia application users } \\
\text { will use the Tokopedia application more often for transactions. } \\
\text { - Tokopedia to be able to maintain and even improve this indicator by } \\
\text { providing promo notifications to Tokopedia users either through the } \\
\text { Tokopedia application, social media, sms, whatsapp chat or via email. } \\
\text { Tokopedia can conduct and share educational videos for consumers } \\
\text { shopping on the Tokopedia application so that transactions can run } \\
\text { smoothly. }\end{array}$ \\
\hline
\end{tabular}

\subsection{Recommendation}

Looking at the results of existing research where there are still many limitations to the research conducted by the author, the recommendations that can be submitted by the author are as follows:

- Seeing the limitations regarding the object of research that only takes respondents, namely users of the Tokopedia application in Surabaya, it is hoped that the next research using the same or modified model can be applied to different objects to get more general results on the factors that affect behavioral intention.

- Further research is expected to complement the existing variables in this research so that it can further enhance the understanding of the factors that affect behavioral intention, such as adding word of mouth or other variables.

- Further research can be developed by linking the factors that influence behavioral intention based on income level, age, and gender. Future research can also expand the scope of respondents who will be researched, or carry out their research in a different area from the current research, so that further research is being conducted to provide a broader picture of behavioral intention

\section{References}

Alba, J., Lynch, J., Weitz, B., Janiszewski, C., Lutz, R., Sawyer, A., Wood, S., 1997.Interactive home shopping: consumer, retailer, and manufacturer incentives to par- ticipate in electronic Marketplaces. Source J. Mark. 61 (3), 38-53.

Beauchamp, M.B., Ponder, N., 2010. Perceptions of retail convenience for in-store and online shoppers. Mark. Manag. J. 20 (1), 49-65.

Bender, W., 1964. Consumer purchase costs—Do retailers recognize them? J. Retail. 11 (1), 1-8.

Berry, L.L., 2000. Cultivating Service Brand Equity. J. Acad. Mark. Sci. 28, 128-137. Berry, L.L., Cooper, L.R., 1990. Competing with time-saving service. Business 40 (2), 3-7. Berry, L.L., Seiders, K., Grewal, D., 2002. Understanding service convenience. J. Mark.

Bhatnagar, A., Misra, S., Rao, H.R., 2000. On risk, convenience, and Internet shopping behavior. Commun. ACM Assoc. Comput. Mach. (ACM) 43 (11), 98-105.

Browne, M.W., Cudeck, R., 1992. Alternative ways of assessing model fit. Sociol. Methods Res. 21 (2), 230258.

Byrne, B.M., 2001. Structural Equation Modeling with AMOS: Basic Concepts, Applications, and Programming. Lawrence Erlbaum Associates, Publishers, Mahwah, New Jersey. 
Comrey, A.L., 1973. A First Course in Factor Analysis. Academic Press, New York. Copeland, M.T., 1923. Relation of consumers' buying habits to marketing methods. Harv. Bus. Rev. 1 (3), 282-289.

Emrich, O., Paul, M., Rudolph, T., 2015. Shopping Benefits of Multichannel Assortment Integration and the Moderating Role of Retailer Type. Journal of Retailing 91. New York University, pp. 326-342.

Farquhar, J.D., Rowley, J., 2009. Convenience: a services perspective. Marketing Theory 9. SAGE Publications, pp. 425-438.

Gehrt, K.C., Yale, L.J., 1993. The dimensionality of the convenience phenomenon: a qualitative reexamination. J. Bus. Psychol. 8 (2), 163-180.

Goyette, I., Ricard, L., Bergeron, J., Marticotte, F., 2010. E-WOM scale: word-of-mouth measurement scale for e-services context. Can. J. Adm. Sci. 27 (1), 5-23.

Gruen, T.W., Osmonbekov, T., Czaplewski, A.J., 2006. eWOM: the impact of customer-to- customer online know-how exchange on customer value and loyalty. J. Bus. Res. 59 (4), 449-456.

Hair, J.F., Black, W.C., Babin, B.J., Anderson, R.E., 2006. Multivariate Data Analysis (6th ed.), Analysis, p. 4.

Hair, J.F., Black, W.C., Babin, B.J., Anderson, R.E., Tatham, R.L., Black, W.C., Hair Jr., J.F., et al., 2010. Multivariate Data Analysis, Prentice Hall, 5th ed. Prentice Hall International, New Jersey.

Haridasan, A.C., Fernando, A.G., 2018. Online or in-store: unravelling consumer's channel choice motives. J. Res. Interact. Mark. 1-16.

Hennig-Thurau, T., Gwinner, K.P., Walsh, G., Gremler, D.D., 2004. Electronic word-of- mouth via consumer-opinion platforms: what motivates consumers to articulate themselves on the Internet? J. Interact. Mark.

Herrmann, R.O., Beik, L.L., 1968. Shoppers' Movements outside Their Local Retail Area. J. Mark. 32 (4), 45-51.

Hsu, C.-L., Chen, M., Chang, K.-C., Chao, C.-M., 2010. Applying loss aversion to in- vestigate service quality in logistics: a moderating effect of service convenience. Int. J. Oper. Prod. Manag. 30 (5), $508-525$.

Hui, M.K., Thakor, M.V., Gill, R., 1998. The effect of delay type and service stage on consumers' reactions to waiting. J. Consum. Res. 24 (4), 469-479.

Javadi, M.H.M., Dolatabadi, H.R., Poursaeedi, A., Asadollahi, A.R., 2012. An analysis of factors affecting on online shopping behavior of consumers. Int. J. Mark. Stud. 4 (5), 81.

Consumers online: intentions, orientations and segmentation. Int. J. Retail Distrib. Manag. Emerald 35 (6), 515-599.

Jiang, L. (Alice), Yang, Z., Jun, M., 2013. Measuring consumer perceptions of online shopping convenience. J. Serv. Manag. Emerald 24 (2), 191-214.

Jih, W.-J. (Kenny), 2009. Service features, customer convenience, and shopping intention in the context of mobile commerce. In: Wang, T.-Y. (Ed.), Comparison-Shopping Services and Agent Designs. IGI Global, Hershey, New York, pp. 134-150.

Jun, M., Yang, Z., Kim, D., 2004. Customers' perceptions of online retailing service quality and their 
satisfaction. Int. J. Qual. Reliab. Manag. Emerald 21 (8), 817-840.

Kaltcheva, V.D., Weitz, B.A., 2006. When should a retailer create an exciting store en- vironment? J. Mark. Am. Mark. Assoc. (AMA) 70 (1), 107-118.

Keaveney, S.M., 1995. Customer switching behavior in service industries: an exploratory Study. J. Mark. 59 (2), 71-82.de Kerviler, G., Demoulin, N.T.M., Zidda, P., 2016. Adoption of in-store mobile payment: are perceived risk and convenience the only drivers? J. Retail. Consum. Serv. 31 (No. July), 334-344.

Kin, N., Farida, N., 2016. Effects of convenience online shopping and satisfaction on re- peat-purchase intention among students of higher institutions in Indonesia. J. Internet Bank. Commer. 21 (2), 1-19.

King, S.F., Liou, J.-S., 2004. A framework for internet channel evaluation. Int. J. Inf.Manag. 24 (6), $473-488$.

Kollmann, T., Kuckertz, A., Kayser, I., 2012. Cannibalization or synergy? Consumers' channel selection in online-offline multichannel systems. J. Retail. Consum. Serv. Elsevier 19 (2), 186-194.

Koo, D., Kim, J., Lee, S., 2006. Personal values as underlying motives of shopping online.Asia Pac. J. Mark. Logist. Emerald 20 (2), 156-173.

Kumar, A., Kashyap, A.K., 2018. Leveraging utilitarian perspective of online shopping to motivate online shoppers. Int. J. Retail Distrib. Manag. 46 (3), 247-263.

Luedi, A.F., 1997. Personalize or perish. Electron. Mark. 7 (3), 22-25.

MacKinnon, K. a., 2012. User generated content vs. advertising: do consumers trust the word of others over advertisers? Elon J. Undergrad. Res. Commun. 3 (1), 14-22.

Madlberger, M., 2009. Exogenous and endogenous antecedents of online shopping in a multichannel environment. In: Wan, Y. (Ed.), Comparison-Shopping Services and Agent Designs. IGI Global, Hershey-New York, pp. 196-216.

Madu, C.N., Madu, A. a., 2002. Dimensions of e-quality. Int. J. Qual. Reliab. Manag. 19 (3), 246-258.

Mehmood, S.M., Najmi, A., 2017. Understanding the impact of service convenience on customer satisfaction in home delivery: evidence from Pakistan. Int. J. Electron. Cust. Relatsh. Manag. 11 (1), 23-43.

Mosteller, J., Donthu, N., Eroglu, S., 2014. The fluent online shopping experience. J. Bus. Res. Elsevier Inc. 67 (11), 2486-2493.

Mpinganjira, M., 2015. Online store service convenience, customer satisfaction and be- havioural intentions: a focus on utilitarian oriented shoppers. J. Econ. Behav. Stud. 7 (1), 36-49.

Narayandas, D., 1998. Measuring and Managing the Benefits of Customer Retention. J. Serv. Res. SAGE Publ. 1 (2), 108-128.

Pan, Y., Zinkhan, G.M., 2006. Exploring the impact of online privacy disclosures on consumer trust. J. Retail. 82 (4), 331-338.

Pappas, I.O., Kourouthanassis, P.E., Giannakos, M.N., Chrissikopoulos, V., 2016.

Explaining online shopping behavior with fsQCA: the role of cognitive and affective perceptions. J. Bus. Res. Elsevier Inc. 69 (2), 794-803.

Park, C., Wang, Y., Yao, Y., Kang, Y.R., 2011. Factors influencing eWOM effects: using experience, 
credibility, and susceptibility. Int. J. Soc. Sci. Humanit. 1 (1), 74-79.

Pham, Q., Tran, X., Misra, S., Maskeliūnas, R., Damaševičius, R., 2018. Relationship be- tween convenience, perceived value, and repurchase intention in online shopping in Vietnam. Sustainability 10 (2), 1-14.

Roy, S.K., Lassar, W.M., Shekhar, V., 2016. Convenience and satisfaction: mediation of fairness and quality. Serv. Ind. J. 36 (5-6), 239-260.

Seiders, K., Berry, L.L., Gresham, L.G., Leonard, L., Larry, G., 2000. Attention, retailers! How convenient Is your convenience strategy? Sloan Manag. Rev. 41 (3), 79-89.

Seiders, K., Voss, G.B., Godfrey, A.L., Grewal, D., 2007. SERVCON: development and validation of a multidimensional service convenience scale. J. Acad. Mark. Sci. Springe. Nat. 35 (1), 144-156.

Shaheed, A., 2004. How convenience has changed the nation. Brand Strategy 44-46. Thompson, B., 2004. Exploratory and Confirmatory Factor Analysis. American Psychological Association (APA), Washington, DC.

Thuy, P.N., 2011. Using service convenience to reduce perceived cost. Mark. Intell. Plan.Emerald 29 (5), 473-487.

Udo, G.J., Bagchi, K.K., Kirs, P.J., 2010. An assessment of customers' e-service quality perception, satisfaction and intention. Int. J. Inf. Manag. 30, 481-492.

Wolfinbarger, M., Gilly, M.C., 2001. Shopping online for freedom, control, and fun. Calif.Manag. Rev. 43 (2), 34-55.

Yale, L., Venkatesh, A., 1986. Toward the construct of convenience in consumer research.Adv. Consum. Res. 13 (1), 403-408.

Zeithaml, V.A., Berry, L.L., Parasuraman, A., 1996. The behavioral consequences of ser- vice quality. J. Mark. 60 (2), 31.

\section{Appendix}

Table 6.1: The Items List Used in the study

\begin{tabular}{|l|}
\hline Access Convenience \\
\hline 1. I can shop whenever I want on the Tokopedia application \\
2. I can order products on the Tokopedia application wherever I am \\
3. I find the Tokopedia application easy to access \\
\hline Search Convenience \\
\hline 1. I find the Tokopedia application easy to use to make purchases \\
2. I find the Tokopedia application easy to navigate within the application \\
3. I can find the product I want quickly on the Tokopedia application \\
\hline Evaluation Convenience \\
\hline 1. I feel that the Tokopedia application ensures that each product has detailed specifications \\
2. I feel that the Tokopedia application uses clear text in product information \\
3. I feel that the Tokopedia application uses an appropriate image in the product information \\
4. I feel that the Tokopedia application provides sufficient information to identify various products \\
\hline
\end{tabular}




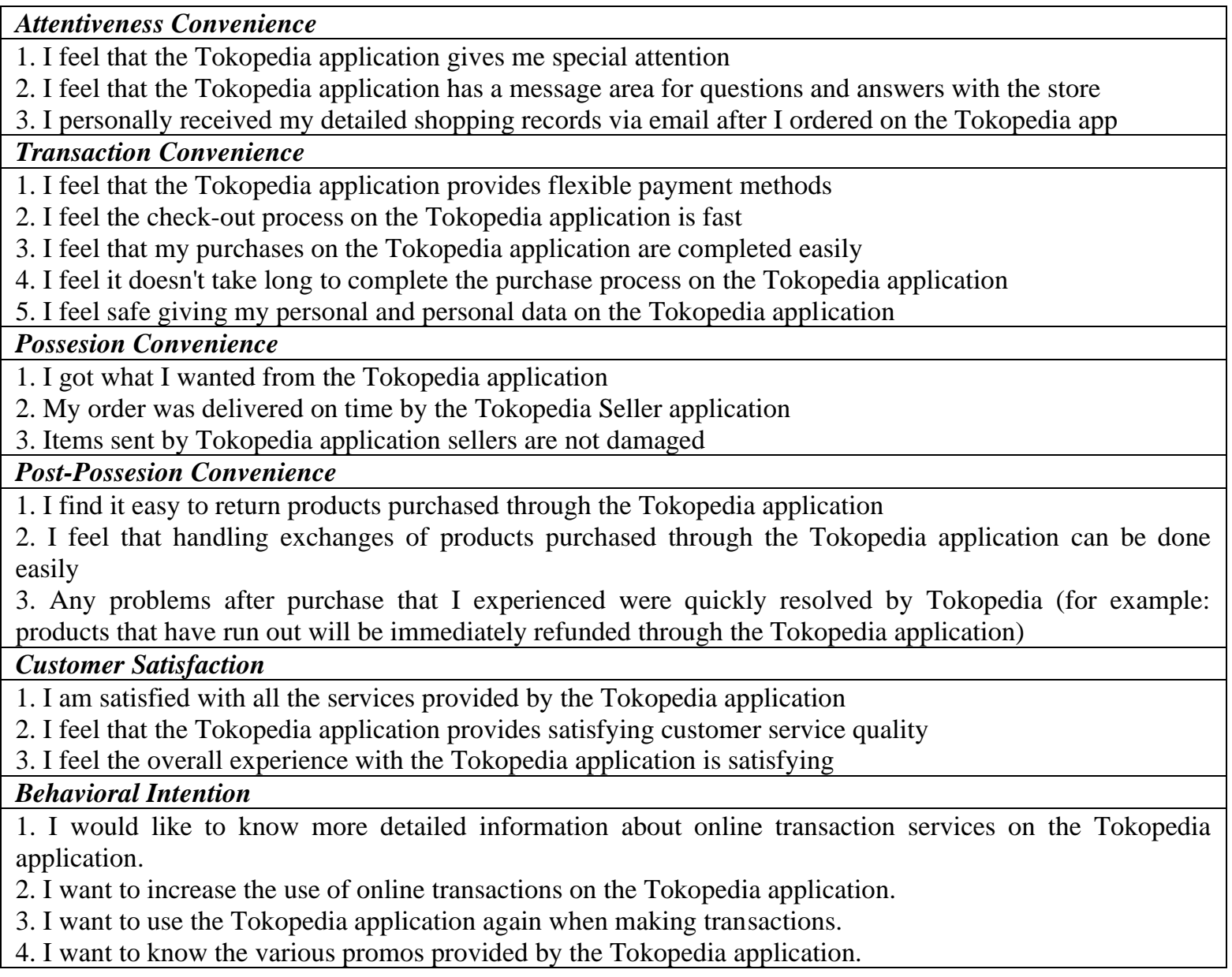

